\title{
TAXATION OF INTANGIBLE PROPERTY
}

\author{
By A. E. James, \\ Special Expert, Committee on Tax Revision, Richmond, Va.
}

The taxation of mortgages differs in principle in no wise from the taxation of other forms of credit. A mortgage is an evidence of a right to share in the income of property, and under certain conditions to assume its legal ownership. A bond, a share of stock, a note secured by collateral, almost any form of intangible property except a personal unsecured note, is in essential legal and economic contemplation no different. Each has its own peculiar procedure for the enforcement of the rights it conveys, but the value of all is essentially based upon the present or potential earning power of the property lying behind the paper. The personal note is of value only because it may also become a lien upon property or because of the confidence felt in the ability of the person to make good his promises. This paper right is property only in the sense that it may be transferred from person to person and enjoys the full protection of the law. In discussing the taxation of mortgages therefore, the theory of the taxation of all intangible property must also be considered.

The laws relating to the assessment and taxation of intangible personal property have, as has often been stated, evolved from the general property tax. The theory is delightfully simple-sufficient reason to account for its stubborn general popularity. Taxes should be paid by those who can afford to pay them, those who have property possess tax-paying ability, therefore measure the taxes by the capital value of property owned.

Under a state of hand trades economics this theory works out a reasonable amount of justice. The essential characteristic of this stage of economic organization is the concentration in the same hands of capital, superintendence and labor. The product is sold near at home, credit is practically unknown, a rough capitation tax reaches the casual laborer, and the property tax reaches savings for they are promptly invested in a local or in fixed property. Coöperative business under this stage is limited to a partnership, the taxation of which differs in no wise from the individual. The union of the factors of 
production in the persons of the partners is still the most common form of organization.

The land or personal property mortgage is the earliest form of credit to evolve from such a stage of society. But the money borrowed is usually procured, not as capital to carry on a business, but as a means to bridge temporary financial difficulties. Eventually, however, borrowing becomes recognized as a legitimate means of obtaining business capital, and the lender is considered as being rightfully entitled to interest as a share of the earnings of the property in which his funds were invested. When this occurs it naturally follows that this financial return to the lender is regarded as taxable property.

The old, old break in logic of course comes at this point. The property mortgaged is already assessed-the successive assessment of the mortgage is a second assessment on the same property or rather on the income of the same property. The answer of the proponent of credit taxation reveals the wide difference in thought of those who favor exemption of credits from those who favor their taxation. The taxation man says-"The owner of these credits enjoys an income, has a property right in his possession, and is as able to pay a tax as the man who happens to hold the physical property." One thinks of taxing things, the other of taxing persons. The whole history of the futile attempts to tax credits is a history of this hazy confusion of thought. The man who proposes to exempt credits argues logically on the basis of the taxation of things, his opponent presses with equal logic the argument for personal taxation.

The invention of modern industrial machinery severed for all time the union of capital, management and labor, and fixed new means for the compensation of these factors for their respective shares in production. Labor and management secured fixed wages, capital took the balance as interest and dividends, according as the intangible evidence of contributions to capital were "bonds" or "stock." A recital of the numerous new forms of business conducting production and transportation is here necessary. Suffice it to say that all the new modes for increasing the comforts and pleasures of life have increased the savings of the people and the possibilities for the further diffusion of those savings in investments of capital far from the home of the owner.

The first result of these changes was to confuse the thought on 
property taxation and the laws providing therefor, the second was to increase the difficulty of enforcement.

Stock in corporations, like personal ownership of property, was early regarded as merged with the property and exempt from taxation. This was natural since early corporations were frequently local and resembled closely the partnerships from which they evolved. But here entered the first wedge in the logic of the property tax. A non-resident corporate stock held by a resident was left taxable, although if his property were held elsewhere as a natural person he would not be taxed except at the situs of the property. Again the confusion of thought-is it the thing or the person that it is desired to tax? The intervention of the artificial person-the corporationmakes clearer the difficulty of the underlying theory of the general property tax. If, as the writer believes, that theory contemplated the taxation of the person, measured by property, the corporation never was a logical subject of such a tax.

Bonds, through their analogy to mortgages were regarded as proper subjects of taxation. Throughout these laws the situs for purposes of taxation is the residence of the owner.

The existence of intangible credits, especially in a form other than mortgages, brings out another weakness of the property taxthe conflict of jurisdictions. The physical property where situated is located and taxed, the intangible is assessed and taxed to the owner where he resides, both on the legal theory that personal property follows its owner and on the economic theory that the person owes a tax allegiance to the place where he lives.

The foregoing is not intended to be historical, but to develop the elements of difficulty inherent in the theory of the tax which have made intelligent readjustment heretofore impossible. Had the change in industrial conditions been uniform, had it affected alike all persons and sections, the proper corrections would have been quickly applied. But at this point entered the difference between city and country. The state legislature was dominated usually by country interests, and the only reform suggested, exemption, was palpably favorable to the wealthy urban residents. The farmers would have none of it. In order that the city might be made to contribute measurably to state taxation the intangible property must in some form be taxed. Moreover the personal ideal-that every man should contribute to the public burden in proportion to his ability 
-was shocked at any proposition wholly to excuse a large and wealthy class of the population from direct taxation.

But not only in economic theory were the difficulties insurmountable. The real breakdown was in administration. Real estate could be seen, so could tangible property of all kinds. The credit, the mortgage, note, bond and stock were veritable will 'o the wisps of taxation. The exemptions written in of stocks of domestic corporations, of federal bonds, of state and local securities left wide open avenues of evasion. The assessor had not only to detect the presence of property, but must ferret out as well its quantity, and its kind. And he was a locally elected officer in a government whose fundamental administrative theory has always been that efficiency consisted largely in getting re-elected. To do his duty he must antagonize those to whom he must appeal to hold his job. And if this were not enough the work he did was looked upon with disfavor by all who could really have done it, and the salary was fixed at about the value of the sort of men willing to accept it.

Reports of tax commissions for years have been filled with the statement of the practical results to which the difficulties enumerated have led. At last nearly everyone has admitted that changes must be made. In the main as regards mortgages these changes have been eight:

\section{First-Exemption.}

Second-Taxation as a share in the property, at the situs of the property and accompanied by a prohibition of any contract by which the mortgagor might agree to assume the tax. (California)

Third-The second plan without prohibiting contracts-a plan really amounting to exemption. (Wisconsin)

Fourth-A low rate of taxation imposed when the instrument is presented for recordation. (New York)

Fifth-A reduced and fixed rate of taxation, assossment made as before. (Maryland)

Sixth - A rigid system of private and public spying with liberal rewards to the spies. (Ohio-Iowa)

Seventh-A rigid centralized administration and a limited rate for all property. (Ohio)

Eighth-Substitution of a progressive income tax for all taxes on intangible personal property. (Wisconsin)

The first named alternative is utterly wrong from the viewpoint of personal taxation. It has found little recent acceptance. The 
second plan fails to tax the person where he lives. It was alleged to have been shifted to the borrower. The third has been superseded by taxation in another form. The sixth is wholly indefensible and has been abandoned. The plans remaining are all of comparatively recent origin and each has points of real value.

The recording tax has the advantage of certainty of assessment and collection and of simplicity in administration. On the other hand it is almost certain to be shifted to the borrower. It gives the tax to the state or county where the mortgage is recorded and not to the civil division in which the mortgagee lives. It cannot be automatically collected for more than a single year, and therefore dries up the source of the revenue, and it creates a special class of credits in mortgages where no logical classification exists. It fails in a word to make the mortgagee pay a reasonable tax.

The fixed limited rate placed low enough to take only a reasonable part of the income has great attractions. It taxes the owner as a person where he resides. It rewards honesty by taxing the security voluntarily returned at a rate which still leaves a very reasonable return to the owner. The most distressing feature of the general laws taxing credits has been the assessment of some credits at face value and the imposition thereon of rates amounting almost to confiscation of the interest. In Virginia, for instance, a special fee paid officer examines the probate and circuit court records and reports for taxation all credits found. As he is appointed by the judge it is very likely that a large part of such securities are found and taxed. But how unfairly! Real estate is grossly undervalued, tangible personal property is little better assessed and credits not under the jurisdiction of this officer scantily returned. The limited low rate corrects these evils and appeals to many as the real solution. Certainly it is as good as any yet developed if the credits are returned. How futile such a. plan is by itself may be illustrated again by Virginia. In 1913 money on deposit was placed in a separate category by the legislature and taxed at twenty cents on the one hundred dollars of valuation. The valuation in 1913 before the law became effective was $\$ 14,002,721$. In $1914, \$ 25,820,978$ was returned. The tax in 1913 was $\$ 208,640.50$, in 1914, \$51,650.89. Bank reports showed deposits in 1914 of $\$ 150,527,998$. The problem is not solved merely by lowering the rate. The taxpayer will not volunteer any tax no matter how low. It must be assessed, and proper machinery must be provided for 
that assessment. The fixed rate plan has a further defect. As public expenditures increase, as increase they must, revenues must increase to meet them. The great strength of the general property tax lies in its elasticity. But as groups are taken out of the general plan of that tax, the rate fluctuations of the remainder must be more violent to meet the changes in revenue demands. Just as the addition of a foot of water to the surface of a placid lake will become a destructive torrent when released to the narrow confines of a river, so a raise in taxes scarcely noticed when spread over the wide area of all property is felt severely if restricted only to a certain class of subjects. A further difficulty which is very real is the adjustment of a fair rate. That rate is not what reasonable persons might regard as a fair portion to take from the income, but the fair tax proportioned to the rate of income taken from other subjects of taxation, due allowance being made for under-assessment but not for non-assessment. This fair tax rate on intangible property varies from country to city and from state to state. It is low in the country and in the South; it is high in the city and in the North. The average tax rate on capital value of $\$ 100$ in Wisconsin is $\$ 1.38$, in Virginia, $\$ .58$. In Milwaukee it is $\$ 1.60$ and in Richmond, $\$ .93$. A fair tax on a credit in Milwaukee would be an unreasonable tax in Richmond, income conditions being equal. Taxes some years ago were found in Wisconsin to take approximately 15 per cent of real estate rentals. The percentage is probably greater now. The railroads of Virginia paid in 1912-1913, 25 per cent of net corporate earnings for taxes, net corporate earnings being net earnings from operation less debt charges. Since the owners of the stock paid such a percentage of their proceeds, should the owners of the bonds pay less? If it be argued that the owner of the farm or of the railroad (stock) has the advantage of the unearned increment on his property it may well be answered that the owner of the mortgage or the bonds had a property of much more stable value and one on which he can in time of need or opportunity more speedily realize.

A lower rate on intangibles frees the tax system of the virtual confiscation so often following occasional assessment. It does not in itself provide for adequate assessment of all credits, it does not meet the revenue demands. It tends to crystallize the revenue system in fixed rates and to render unstable the rates on all property remaining in the general property plan. These objections are met 
by the new plan of Ohio. A low fixed limit is placed on all property, centralized assessment is provided by assessors appointed under civil service by the state tax commission. The weakness of the Ohio system lies in the attempt to place an arbitrary limit upon all taxes. This limit must be so low as seriously to cripple the legitimate functions of some governmental units or so high as not to restrict materially gross extravagance in the vast majority.

The Ohio plan further denies the dissimilarity of things which are really different and which should be differently treated for purposes of taxation. The income of intangible property comes to the owner net, of tangible property, plus charges for all the losses to which such property is subject. The capital value of the latter shifts daily as these numerous factors of expense increase or diminish. The capital value of a note or mortgage is named in the instrument itself. The income from tangible property may, within limits, be made to conform to an increased demand for taxes, the same change is not so easily accomplished in the case of credits. These fundamental differences should be recognized in all legislation dealing with the taxation of these classes of property.

There remains to be considered the most radical plan adopted by any state as a means of reaching intangible property-the Wisconsin income tax. This tax exempts intangible property from taxation and levies a tax upon all incomes above certain reasonable exemptions. The tax is administered by a central state commission which appoints under civil service and controls the assessors of incomes themselves. The rates provided in the law grade from 1 per cent on the first $\$ 1,000$ of taxable income to 6 per cent when the income reaches $\$ 12,000$. A tax is also levied upon corporations and partnerships. The law is far from perfect. It levies a heavier tax upon corporations than upon individuals and partnerships. It is designed not merely as a means whereby to tax the owner of intangible property, but of tangible property as well. The tax on corporations and partnerships is not a mere device to stop the income at the source, but taxes the corporate and partnership income as such independently of any tax liability on the part of the owners behind these mere fictitous creations of the law. The location of the property producing the income and not of the taxpayer is the test of taxability. The law shares the weakness of the recording taxes and special fixed rate levies in that the rates are laid wholly without refer- 
ence to the revenue demands of the government. On the other hand it is eminently strong in the administrative features and the incomes are assessed. Unfortunately, because the individual, corporate and partnership provisions are complicated by offsets and exemptions, there are no statistics available which really show what incomes of individuals were really declared. The report of the Wisconsin commission for 1912 shows the assessment of income for the first year of the tax to have been $\$ 100,845,863$ of which $\$ 44,311,315$ was income of corporations and $\$ 56,534,548$ was returned by individuals and partnerships. If all the owners of Wisconsin corporations and partnerships were located in Wisconsin and Wisconsin people owned no outside securities the $\$ 100,000,000$ would of course represent the individual income actually returned. The highest assessment of intangible property ever made in Wisconsin was only $\$ 73,055,104$.

It will be seen that all the systems now in use by those states most advanced in tax reform wherewith intangible property is sought to be taxed, are defective to a greater or less extent. The writer believes that these defects arise from the same cause that has led to the failure of the general property tax to reach intangibles. The makers of all these laws appear not to have thought clearly whether it is the person or the property that is to be taxed. The writer believes there are two legitimate situs claims for taxes-the one where tangible property is found, the other where the personal owner of that property resides. This belief is not founded upon any benefit theory of taxation. Wherever property and government exist together, even in a wilderness, there must be means provided for the support of government, and property supplies those means. Wherever persons and government exist together the government must live and those persons must in some form share in its support. The ability to pay is measured in the one case by capital value, in the other by income. Either form of tax is unworkable without the other. No government in a new country could afford to wait upon the uncertain exigencies of incomes arising from the property within its borders, a crowded city supporting a great population only casually connected with tangible property cannot justly ignore incomes as a source of revenue. Alongside of these a third class must be mentioned - those persons, either corporeal or corporate, who through the ownership of special privileges operate certain kinds of enterprises of a non-competitve character. Transportation, banking, 
insurance and the services of heat, light and power are of this kind. Such enterprises should not be assessed like property, but as units, including in one assessment the real, tangible personal, and intangible going values.

The matter of tax rates remains to be considered. It is believed that all subjects of taxation should feel alike the expenses of government and if those expenses increase all should share in the added burden. Tax rates fixed on one class of tax payers and elastic as to others are bad both because they render the one class indifferent to their civic duties, and the other unduly sensitive to changes in the rates. They invite legislative extravagance if the fixed revenues exceed legitimate demands, and compel niggardliness if the fixed sources fall short of expectations.

All taxes on tangible property should be at uniform rates within the locality levying the tax. Such an adjustment is simple, and works no hardship. In competitive business (where taxes are merely one of the elements of expense, and as such included in the selling price) the adjustment to the conditions imposed by such taxes is easy and simple. Comparative stability of rates is more important to competitive business than is the amount of the tax.

The rates on tangible property should also be imposed upon non-competitive business under the unit assessments. The rate on personal incomes (there should be no other income tax), imposed in lieu of all taxes on occupations and intangible property should never be less on the income than the tax rate on the capital value of property. It should be adjusted with a view to a rough approximation, at least, to the demands on the income of tangible property. If the progressive principle be applied, the rate should start well below this burden and end well above it so that the average may be reasonably close to the normal tax rate. To be specific: If a tax rate of one per cent takes ten per cent of property income, the income tax rate if it start at one per cent should progress so that the average income tax payer of that community would pay ten per cent. If the tax rate should then become two per cent the primary income rate and all the progressive rates should be increased by this one per cent. In this manner the personal taxpayer is made to take pot-luck with all others, and has an equal interest in public expenditures. This plan may be applied to each locality, to counties and to the state. It is simple. It supplies the proper demand for 
personal taxation. It makes the personal tax reasonable-as the general property tax is not. It is flexible-as the substitutes, heretofore suggested, are not.

There should be no misunderstanding of one fact which all recent reforms make clear. No law is half so badly needed as is an honest and efficient administration of such laws as we may have. True, vicious laws form an excuse for non-enforcement, but it is mainly an excuse. The fact is that efficient and fearless law enforcement in taxation especially is so foreign to American experience that no one can say how well the laws we have had would have worked had proper machinery been provided for their enforcement. The auditor of Virginia added $\$ 50,000,000$ to the assessment of intangible property in two years by a vigorous exercise upon local officials of the mere power of persuasion. A few such real serious administrative efforts are worth a thousand volumes of Utopian legislation. After all, taxation, both on the part of the taxpayer and tax assessor, is a personal matter and can work well only when gone about with the same honesty and seriousness of purpose that characterizes the bulk of the other personal contacts of humanity.

Note-Since the above discussion deals primarily with the taxation of intangible property, and only with other subjects so far as their discussion was necessarily coupled with the main theme, it should be understood that the detailed views of the writer as to the taxation of tangible personal property, increment taxation, inheritance taxes and others not a necessary part of a property tax, are not expressed. 